Academic Libraries as High-Tech Gateways: A Guide to Design and Space Decisions, by Richard J. Bazillion and Connie Braun (225 pages, May 1995), focuses on physical access to online information systems and the design of electronic study centers. The authors provide their recommendations for making the facility as user-friendly as the software. $\$ 40.00$ (ALA members, \$36.00). ISBN 0-8389-0656-7.

A related title from ALA Editions, Planning Additions to Academic Library Buildings: A Seamless Approach, edited by Pat Hawthorne and Ron C. Martin (40 pages, May 1995), shows how to incorporate the features of existing structures in a new addition without compromising functionality. $\$ 25.00$ (ALA members, \$22.50). ISBN 0-8389-0651-6. American Library Association, Book Order Fulfillment, $155 \mathrm{~N}$. Wacker Dr., Chicago, IL 60606-1719.

\section{Baltimore's Past: A Directory of Histori-} cal Sources, compiled by the Baltimore Archives Network (255 pages, May 1995), provides the name, address, phone and fax numbers, hours of service, and a description of the holdings of more than 140 institutions, museums, and repositories with holdings open to researchers who are undertaking historical or genealogical research in the Baltimore Metropolitan area. $\$ 15.00$ (plus $\$ 1.75$ handling). Historyk Press, 7 Dendron Court, Baltimore, MD 21234. ISBN 1-8871-2411-X.

\section{Blacks in Black and White: A Source} Book on Black Films, by Henry T. Sampson (735 pages, $2 \mathrm{~d}$ ed., April 1995), traces the history of the black film industry from its beginnings around 1910 to its demise in 1950. This new edition offers significantly more information on Oscar Micheaux and other African American producers of the period and new material that shows how the themes of these early films changed over the years. The filmography and the lists of black film production companies and black filmmaker credits have been expanded; a list of theaters that catered to black audiences and a filmography of video- like Soundies featuring black musicians are new to this edition. Many illustrations, film reviews, and biographies are included. $\$ 89.50$. Scarecrow Press, 4720 Boston Way, Lanham, MD 20706. ISBN 0-8108-2605-4.

Building Partnerships: Computing and Library Professionals, edited by Anne G. Lipow and Sheila D. Creth (102 pages, April 1995), contains the papers presented at the Library Solutions Institute Number 3, held in Chicago, May 12-14, 1994, and cosponsored by Library Solutions Institute and CICNet, Inc. Sixty-one academic librarians and computing professionals met to eradicate stereotypes about each other and work together to launch collaborative projects that they felt could be accomplished upon returning home. The proceedings include four formal presentations as well as post-institute reports by participants on projects underway on their campuses. Also reprinted is Creth's pre-institute reading assignment, "Creating a Virtual Information Organization," in which she suggests methods for collaboration. $\$ 29.00$. Library Solutions Press, 1100 Industrial Road, Suite 9, San Carlos, CA 94070. ISBN 1-882208-18-8.

Certified Course in C, by David Himmel (393 pages, July 1995). What me? Program in C? For anyone with a modest technical aptitude and little fear of the word "programming," this book could be the source of new skills and opportunities. It comes with a working version of Borland's Turbo $\mathrm{C}++$ compiler and an opportunity to earn collegiate certification and credits. $\mathrm{C}++$ has emerged as the language of choice for commercial software products written for MS-DOS/Windows computers. If you're only mildly deterred by chapter headings like "Functions with Pointer Arguments and Return Values" or "Directives for Conditional Compilation," Himmel's manual might open up new career

George Eberbart is editor and compiler of The Whole Library Handbooks for ALA Editions (1991, 1995). He served as editor of C\&RL News from 1980 to 1990 . 
vistas. \$39.95. Waite Group Press, 200 Tamal Plaza, Corte Madera, CA 94925. ISBN 1-87873992-1.

The Columbia Dictionary of Modern Literary and Cultural Criticism, edited by Joseph Childers and Gary Hentzi (362 pages, April 1995), unveils the meaning behind all those social studies terms that have recently invaded everyday life and speech. Armed with this book, you can venture unafraid into essays and monographs that blithely ramble on about deconstruction, schizoanalysis, pathetic fallacy, anxiety of influence, and-yes-postmodernism without feeling that you are reading a Sanskrit epic. Most of the 450 entries include a bibliography of the essential texts, while a separate name index makes it easy to trace the influence of specific scholars, \$49.50. Columbia University Press, 562 W. 113th Street, New York, NY 10025. ISBN 0-231-07242-2.

\section{Doing More Business on the Internet,} by Mary J. Cronin (368 pages, 2 d ed., June 1995), is an update of last year's book, but as Net users know, the World Wide Web has evolved into a completely different animal in a short period of time. Like the earlier edition, this speaks directly to the business community (and M.B.A. candidates) by demonstrating the advantages of Web sites and direct customer connections. Cronin anchors her arguments to solid data by demonstrating how companies as diverse as $\mathbf{J}$. P. Morgan, Schlumberger, and Rockwell International have used the Internet strategically and cost-effectively. As The Economist quipped, "if you're not on the net,
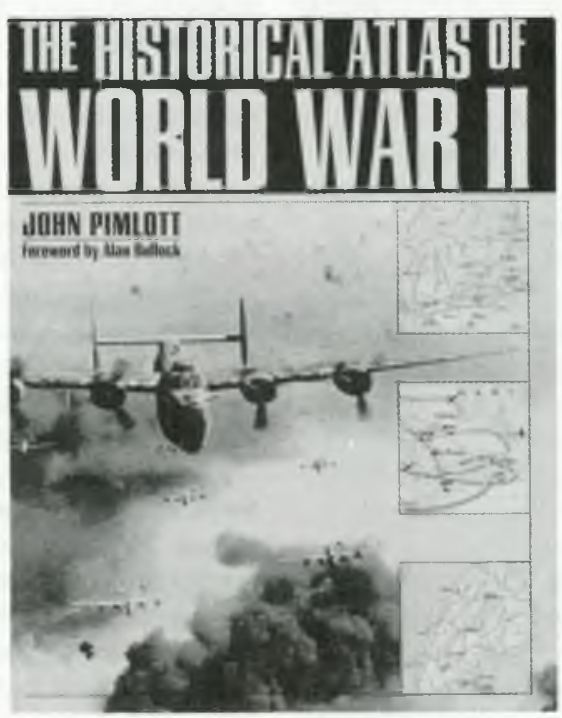

Bentley (286 pages, plus Telescan software, July 1995), which emphasizes the practicalities and strategies of monitoring stocks electronically. \$49.95. ISBN 0-471-11926-1. Hook Up, Get Hired!, by Joyce Lain Kennedy (250 pages, July 1995), which offers practical tips for finding jobs online (mostly computer-related, but this may change). $\$ 29.95$. ISBN 0-471-11629-7. Both from Wiley, 605 Third Ave., New York, NY 10158. And the Online Marketing Handbook, by Daniel S. Janal (370 pages, May 1995), which is a practical and well-illustrated manual on selling products and services on both the Internet and other commercial online systems. \$24.95. Van Nostrand Reinhold, 115 Fifth Ave., New York, NY 10003. ISBN 0442-02058-9.

\section{Emerging Democracies and Freedom of} Information, edited by Barbara Turfan (192 pages, May 1995), contains papers on writers and governments, the abuse of human rights, democracy and Islam, freedom of information in South Africa, and library information access issues in countries adjusting to democracy. The essays are divided into three geographical ar- you're not in the know." $\$ 29.95$. Van Nostrand Reinhold, 115 Fifth Ave., New York, NY 10003; http://www novalink.cum/cronin. ISBN 0-44202047-3.

Some other business-related Internet books that I can recommend are Cyber-Investing: Cracking Wall Street with Your Personal Computer, by David L. Brown and Kassandra eas: the Far East, Russia and Eastern Europe, and Africa. 225.95 . Library Association Publishing, 7 Ridgmount Street, London, England, WC1E $7 \mathrm{AE}$. ISBN 1-85604-170-0.

\section{The Encyclopedia of} the Sword, by Nick Evangelista (690 pages, May 1995), serves as both a glossary of fencing terms and a repository of facts concerning actors and films in which swordplay is prominent. Equal time is given to historical, mythical, and Japanese swordsmanship, so that this can be used as a literary reference as well as a sportsman's guide. \$79.50. Greenwood Press, 88 Post Road West, P.O. Box 5007, Westport, CT 06881-5007. ISBN 0-313-27896-2.

The Historical Atlas of World War II, by John Pimlott (223 pages, June 1995), is a worthy addition to the genre of World War II at- 
lases. The maps are well drawn and informative, and show broad strategic operations like the Winter Offensive in the Ukraine as well as such tactical deployments as the fall of Tobruk and Tarawa Atoll. The commentary is concise and the illustrations are minimal, allowing the cartography to take the leading role. A nice companion to Anthony Livesey's Historical Atlas of World War I (192 pages, September 1994), also published by Holt. $\$ 45.00$. Henry Holt and Co., $115 \mathrm{~W}$. 18th St., New York, NY 10011. ISBN 0-8050-3929-5.

\section{The Gay and Lesbian Literary Heritage,} edited by Claude J. Summers ( 786 pages, June 1995), brings together scholarship on the literary representation of homosexuality in the form of a reader's guide. More than 350 essays establish the presence of gay and lesbian themes in a variety of genres, countries, and historical periods. In addition to particular authors, this volume covers such issues as camp, decadence, identity, AIDS, bisexuality, and romantic friendship. Since much of the literature has been misinterpreted by straight literary critics, this book sets the record unstraight. $\$ 45.00$. Henry Holt, 115 W. 18th St., New York, NY 10011. ISBN 0-8050-2716-5.

\section{Hunters and Shooters: An Oral History of the U.S. Navy SEALs in Vietnam, edited by Bill Fawcett ( 288 pages, July 1995), presents the first-person accounts of 15 combat veter- ans who fought in Vietnam, the earliest prov- ing ground for the Navy's SEa, Air and Land (SEAL) teams. Their descriptions of SEAL train- ing and combat operations are grim reminders of a war that many now regret the United States was ever involved in. $\$ 23.00$. William Morrow and Co., 1350 Avenue of the Americas, New York, NY 10019. ISBN 0-688-12664-2.}

\section{Indigenous Literature of Oceania: A Sur-} vey of Criticism and Interpretation, by Nicholas J. Goetzfridt (347 pages, March 1995), is an extensive annotated bibliography of criticism relating to poetry, fiction, and drama written in English by indigenous peoples of the South Pacific, New Zealand, and Australia. The listings are largely confined to academic and literary journals and books. \$75.00. ISBN 0-31329173-X. Also of interest is Micronesian Religion and Lore: A Guide to Sources, $1526-$ 1990, by Douglas Haynes and William L. Wuerch (300 pages, March 1995), which re- views 1,193 titles dealing with myth, legend, and ritual in the Marianas, Carolines, and Gilbert and Marshall Islands. \$75.00. ISBN 0-313 28955-7. Both published by Greenwood Press, 88 Post Road West, P.O. Box 5007, Westport, CT 06881-5007.

\section{Magnetic Tape Storage and Handling:} A Guide for Libraries and Archives, by John W. C. Van Bogart (34 pages, June 1995), details the long-term storage requirements for magnetic media and offers advice on how to care for tapes in order to maximize their life expectancies. Van Bogart, who is principal investigator for media stability studies at the National Media Laboratory, provides the rationale be hind recommended procedures, which might be used to support cost-benefit arguments to administrators. $\$ 10.00$. Committee on Preservation and Access, 1400 16th St. N.W., Suite 740 , Washington, DC 20036. ISBN 1-887334$40-8$.

\section{Shakespeare Companies and Festivals:}

An International Guide, edited by Ron Engle, Felicia Hardison Londré, and Daniel J. Watermeier (568 pages, May 1995), describes more than 150 Shakespeare troupes and performances worldwicle. Each profile describes the history of each company, its staffing and budget, its physical facilities, the demographics of its audience, its approach to producing the plays, audition procedures, and production history. Of particular interest are the innovative German-language festivals and the China Shakespeare Festival, which incorporates traditional Chinese theater practices. \$95.00. Greenwood Press, 88 Post Road West, P.O. Box 5007 , Westport, CT 06881-5007. ISBN 0-313-27434-7.

\section{Soren Kierkegaard Bibliographies: Rem-} nants, 1944-1980, and Multi-Media, 19251992, compiled by Calvin D. Evans (May 1995), are a component of the International Kierkegaard Bibliographic Database. Remnants includes 221 books, 201 articles, and 142 dissertations which have never before been included in a published bibliography or which supply additional information or corrections to alreadypublished works. The multimedia section lists audiotapes, films, music, radio, slides, and theatrical performances. $\$ 25.00$ (plus $\$ 5.00$ shipping). Director of Libraries, McGill University Libraries, 3459 McTavish Street, Montreal, Quebec, Canada H3A 1Y1 
Style: Toward Clarity and Grace, by Joseph M. Williams (208 pages, June 1995), explains, without going into the intricacies of syntax and grammar, how writers can improve the style of their reports, articles, memos, and books, and clarify complexities in their chosen subjects. Indeed, pop grammarians with narrow definitions of prose propriety are derided for their folklore and foibles. The ultimate objective of competent exposition is stressed, with many examples of how to achieve that goal. Those who feel that structure is more important than effective communication may feel slighted; however, these days both readers and writers need as much help as they can get in conveying and interpreting complex ideas. \$9.95. University of Chicago Press, 5801 S. Ellis Ave., Chicago, IL 60637. ISBN 0-22689915-2.

\section{Upside Your Head! Rhythm and Blues} on Central Avenue, by Johnny Otis (174 pages, July 1995), is a trade paperback edition of Otis's outspoken 1993 memoir on his early days in R\&B. Otis reminisces about the black cultural scene on Central Avenue in the 1940s, which was Los Angeles' Harlem Renaissance, and his encounters with musicians such as Lester Young, Little Esther Phillips, Etta James, T-Bone Walker, and many others. He also pulls no punches in his indictment of society's racism, both then and now, and the theft of African American musical styles by white musicians. $\$ 16.95$. University Press of New England, 23 South Main St., Hanover, NH 03755 . ISBN 08195-6287-4

\section{Whales, Dolphins and Porpoises: The} Visual Guide to All the World's Cetaceans, by Mark Carwardine (256 pages, 1995), is one of the latest Eyewitness Handbooks pullished by Dorling Kindersley. Like the others in this series, each animal is carefully illustrated with callouts that highlight its distinctive characteristics. There is an identification checklist for each species, along with distribution maps, tips on where to observe whales, and notes on behavior. The introduction even lists dos and don'ts for dealing with stranded live animals. Ultimately, the guide contains less information than The Sierra Club Handbook of Whales and Dolphins (Random House, 1983) or Lyall Watson's Sea Guide to Whales of the World (Dutton, 1981), but its color, illustrations, and ease of use make it an excellent field guide.
\$29.95. Dorling Kindersley Publishing, Inc., 95 Madison Ave., New York, NY 10016. ISBN 156458-621-9.

\section{Statement of ownership and management}

College E Research Libraries News is published 11 times a year (monthly, combining July/August) by the American Library Association, 50 E. Huron St., Chicago, IL 60611. American Library Association, owner; Mary Ellen K. Davis, editor and publisher. Second-class postage paid at Chicago, Illinois. Printed in the U.S.A. As a nonprofit organization authorized to mail at special rates (DMM Section 423.12), the purposes, function, and nonprofit status of this organization and the exempt status for federal income tax purposes, have not changed during the preceding 12 months.

\section{Extent and nature of circulation}

("Average" figures denote the number of copies printed each issue during the preceding twelve months; "Actual" figures denote the number of copies of single issues published nearest to filing date.)

Total number of copies printed: Average, 12,304; Actual, 12,322. Sales through dealers and carriers, street vendors, and counter sales: not applicable. Paid or requested mail subscriptions: Average, 11,472; Actual, 11,592. Total paid and/or requested circulation: Average, 11,472; Actual, 11,592. Free distribution by mail: Average, 44; Actual, 32. Free distribution outside the mail: Average, 0; Actual, 0. Total free clistribution: Average, 44; Actual, 32. Total distribution: Average, 11,516; Actual, 11,624. Copies not distributed: Office use, leftover, spoiled: Average, 788; Actual, 698. Returns from news agents: not applicable. Total (sum of previous entries): Average, 12,304; Actual, 12,322. Percent paid and/or requested circulation: Average: 99.62\%; Actual: $99.72 \%$.

Statement of Ownership, Management, and Circulation (PS Form 3526, October 1995) for 1995 filed with the United States Postal Service, Postmaster in Chicago, Illinois, October 5, 1995. 


\title{
Association of College and Research Libraries
}

\section{Why did nearly 11,000 academic librarians and staff join ACRL?}

\author{
World-class publications \\ Standards, Guidelines \\ Advisory services \\ Leadership roles \\ Networking \\ Discounts \\ Sections \\ Advocacy \\ Newsletters \\ Local chapters \\ Career resources \\ Awards, Fellowships \\ Professional development \\ Electronic communications

\section{Find out what ACRL can do for you!}

Call: 1-800-545-2433, ext. 2521 or 2510 E-mail: cynthia.taylor@ala.org or noreen.hale@ala.org 